\title{
CIRCUIT TRAINING: MODEL LATIHAN UNTUK MENUNJANG KETEPATAN PUKULAN BACKHAND BULUTANGKIS
}

\author{
Puja Perdana Putra ${ }^{* 1}$, Rufi' ${ }^{2}$, Abd Cholid ${ }^{3}$ \\ Universitas PGRI Adi Buana Surabaya, Indonesia ${ }^{1,2,3}$ \\ Email: pujaperdanaputra@gmail.com ${ }^{* 1}$, rufii@ unipasby.ac.id ${ }^{2}$, abdcholid.coach@gmail.com ${ }^{3}$
}

Received: 12 February 2020; Accepted 01 June 2020; Published 15 June 2020

Ed 2020; 5(1): 84-96

\begin{abstract}
ABSTRAK
Penelitian ini bertujuan mengembangkan model latihan circuit training, kemudian menghasilkan buku ajar yang sesuai dan mempermudah atlet belajar ketepatan pukulan backhand. Penelitian ini melalui beberapa tahapan meliputi: uji coba ahli desain pembelajaran dan ahli materi bulutangkis, pembuatan angket yang divalidasi oleh ahli materi bulutangkis dan ahli psikologi olahraga, uji coba lapangan mulai teman sejawat beserta atlet, pelatih kelompok kecil beserta atlet dan pelatih kelompok besar beserta atlet. Tempat uji coba pada pelatih di Persatuan Bulutangkis Patriot Sidoarjo. Teknik pengumpulan data menggunakan angket dengan menilai respon para pelatih dan atlet bulutangkis dan dianalisis menggunakan statistik deskriptif. Hasil penelitian ini menunjukkan bahwa uji validasi produk oleh ahli desain pembelajaran dan ahli materi, uji coba lapangan mulai dari teman sejawat dan atlet bulutangkis, uji coba kelompok pelatih kelompok kecil dan atlet kelompok kecil, uji lapangan pelatih kelompok besar dan atlet kelompok besar termasuk kategori baik, dengan demikian pengembangan model latihan circuit training untuk menunjang ketepatan pukulan backhand bulutangkis layak digunakan oleh para pelatih.
\end{abstract}

Kata Kunci: Model Latihan; Circuit Training; Ketepatan; Backhand; Bulutangkis

\section{CIRCUIT TRAINING: TRAINING MODEL TO SUPPORT THE ACCURACY OF BACKHAND IN BADMINTON}

\begin{abstract}
The objective of this research was to develop circuit training exercise model to increase the accuracy of backhand strokes for badminton athletes and trainers. This research was conducted by several stages which started from validation stage by instructional design expert and content expert, then designing questionnaire which was validated by content expert and sports psychology expert, testing stage to colleagues, athletes as group and wide group. This testing was carried out in Patriot Sidoarjo Badminton Federation. The instrument of this research was questionnaire from coaches' response and athletes' response. Those responses were analyzed by descriptive statistics. The finding shows that the results of validation from content expert and instructional design expert, testing to small group and wide group, and implementation testing were good category. It can be concluded that this model that is intended to increase backhand strokes in badminton is valid to adopted by badminton coaches.
\end{abstract}

Keywords: Exercise Model; Circuit Training; Accuracy; Backhand; Badminton

Copyright @ 2020, Journal Sport Area

DOI: https://doi.org/10.25299/sportarea.2020.vol5(1).4634

How To Cite: Putra, P.P., Rufi'i., \& Cholid, A. (2020). Circuit Training: Model Latihan Untuk Menunjang Ketepatan Pukulan Backhand Bulutangkis. Journal Sport Area, 5(1), 84-96.

\section{PENDAHULUAN}

Olahraga adalah latihan fisik yang baik dalam menjaga dan meningkatkan kebugaran jasmani. Kebugaran jasmani merupakan kemampuan seseorang dalam menjalankan kegiatan fisik yang membutuhkan kekuatan, daya tahan, serta fleksibilitas (Bompa, 2015). Kemudian Menurut Sajoto dalam Trisandy dan Sugiyanto (2017) 
kebugaran jasmani atau kondisi fisik merupakan satu kesatuan yang utuh dari komponen-komponen yang tidak dapat dipisahkan begitu saja baik dari segi peningkatan ataupun pengolahannya. Komponen kondisi fisik meliputi: kekuatan, daya tahan, kecepatan, kelenturan, kelincahan, koordinasi, keseimbangan, dan ketepatan.

Olahraga tidak akan pernah lepas dari kehidupan manusia, setiap hari pasti melakukannya (Prasetyo, 2013). Olahraga adalah setiap kegiatan tubuh yang meningkatkan atau mempertahankan kebugaran fisik dan kesehatan serta kebugaran secara keseluruhan (Gokulkrishnan, 2018). Selain olahraga dapat menyehatkan badan, olahraga bisa juga dijadikan sebagai saran bermain. Olahraga menurut United Nations Educational, Scientific, and Cultural Organization (UNESCO) adalah suatu aktivitas yang dilakukan tubuh dalam bentuk permainan untuk berjuang melawan alam, orang lain, atau diri sendiri. Olahraga adalah segala aktivitas fisik yang sistematis untuk mendorong, membina, dan mengembangkan potensi jasmani, rohani dan sosial (Maksum, 2011). Dalam Undang-Undang Nomor 3 tahun 2005 disebutkan bahwa olahraga adalah segala kegiatan yang sistematis untuk mendorong, membina dan mengembangkan potensi jasmani, rohani, dan sosial (Mutohir, Muhyi, \& Fenanlampir, 2011). Keolahragaan memiliki tujuan memelihara dan meningkatkan kesehatan dan kebugaran, prestasi, kualitas manusia, menanamkan nilai moral dan akhlak mulia, sportifitas, disiplin, mempererat dan membina persatuan dan kesatuan bangsa, memperkukuh ketahanan nasional, serta mengangkat harkat martabat dan kehormatan bangsa (Yani, 2015).

Indonesia memiliki banyak olahraga yang digeluti oleh masyarakat secara umum dan atlet secara khusus. Dari berbagai olahraga yang ada dunia, olahraga bulutangkis berkesan sangat baik dan menuai banyak prestasi, tak heran bila olahraga ini menjadi hobi semua kalangan di Indonesia, mulai dari tingkat desa hingga nasional. Sekolah dan lembaga lain juga memiliki gedung bulutangkis untuk mengasah skill atau hanya untuk berolahraga biasa. Bulutangkis adalah olahraga yang menggunakan raket yang dapat dilakukan dengan cara satu orang melawan satu orang atau dua orang melawan dua orang (Juang \& Widodo, 2015). Bulutangkis adalah olahraga dinamis yang sangat kompetitif yang membutuhkan banyak tuntutan pada sistem kardiorespirasi dan otot (Abdullah, 2014).

Bulutangkis adalah olahraga yang menuntut fisik, membutuhkan kekuatan, daya tahan, kekuatan otot, kelincahan, kecepatan dan ketepatan (Song, Peng, Hu, \& Liu, 2020). Perkembangan bulutangkis di dunia terus berkembang, bahkan Indonesia dikatakan memiliki atlet yang berkontribusi besar dalam skill dan teknik unik dalam bulutangkis. Hal ini selaras dengan pernyataan (Poole, 2005) bahwa bulutangkis masih terus berkembang, makin populer, membutuhkan ketangkasan, tantangan, dan memberikan banyak kesenangan. Beberapa teknik tersebut memiliki berbagai macam cara untuk meningkatkan ketangkasan, di antaranya adalah penguasaan teknik-teknik dasar pukulan (Pratomo, Sugiharto, \& Subiyono, 2013). Bahkan teknik dasar diajarkan sejak pemula dari segala tingkatan. (Taufan, Dewantara, \& Alsaudi, 2016).

Teknik latihan bulutangkis akan sangat berpengaruh untuk mengasah kualitas dan gaya bermain agar dapat meningkatkan skill atau kemampuan yang baik. Salah satu teknik latihan pada bulutangkis yakni latihan circuit training. Teknik latihan ini pada setiap cabang olahraga tidak sama cara melatihnya. Komponen-komponen circuit training bergantung dari peran dan beban kerja pada setiap cabang olahraga tersebut (Romadhoni, Herawati, \& Pristianto, 2018). Frekuensi latihan circuit training sebaiknya 3 kali seminggu, sirkuit dilakukan 2-3 tiap pos, 6-15 pos, beban latihan antara 40\%-50\% 
dari maksimal ulangan tunggal, jumlah repetisi tiap pos 75\%-100\% dari jumlah maksimal yang bisa dicapai dari periode kerja dan periode kerja 15-30 detik dan periode waktu istirahat 15-60 detik (Rahman, 2018).

Latihan circuit training adalah suatu program latihan yang dikombinasikan dari beberapa item-item latihan yang tujuannya dalam melakukan suatu latihan agar tidak membosankan dan lebih efisien (Kusuma, 2017). Fungsi dari circuit training untuk mempermudah pelatih dan atlet dalam melakukan variasi latihan dan lebih fokus untuk suatu pencapaian yang sudah ditetapkan oleh pelatih untuk para atlet. Latihan circuit training secara tidak langsung akan mempengaruhi keberhasilan suatu permainan bulutangkis. Sehingga kualitas teknik dasar dalam permainan bulutangkis akan menjadi lebih baik dengan pola latihan yang baik dan benar. Berdasarkan hal ini atlet atau pemain harus benar-benar menguasai teknik-teknik dasar dari permainan bulutangkis (Putra \& Sugiyanto, 2016).

Latihan metode circuit traning telah banyak diuji coba diberbagai latihan olahraga yang lain. Penelitian Mohanta, Kalra, dan Pawaria (2019) menunjukkan bagaimana circuit training efektif dalam meningkatkan kekuatan variabel kekuatan tungkai atas dan bawah, kelincahan dan berlari dalam olahraga tenis. Begitu pula, penelitian Babu dan Kumar (2013) menunjukkan bahwa circuit training sangat efektif diterapkan pada pelari pemula untuk meningkatkan kualitasnya. Penelitian lain Sonchan, Moungmee, dan Sootmongkol (2017) memaparkan bagaimana circuit training sangat efektif untuk meningkatkan kekuatan otot, kelincahan dan ketahanan kardiovaskular pada atlet aerobik.

Berdasarkan observasi yang telah peneliti lakukan pada Persatuan Bulutangkis (PB) Patriot pada saat latihan maupun pada saat pertandingan peneliti melihat ada beberapa kendala atau masalah yaitu: atlet mengalami kelelahan yang diakibatkan teknik pukulan yang belum sempurna, atlet sering kali mengalami penurunan pergerakan kaki di lapangan, atlet sering kali gagal pada pukulan backhand sehingga berdampak pada performa latihan dan pada saat pertandingan, dilihat dari pertandingan atlet terlihat tidak stabil dalam pertandingan panjang dan terlihat atlet sangat terburu-buru untuk menyelesaikan pertandingan tanpa melihat atau memperhitungkan pukulan-pukulan yang kurang tepat (pukulan backhand). Teknik backhand sulit dilakukan karena untuk menggerakkan posisi tubuh dan melakukan backhand membutuhkan waktu dan gerak kaki yang benar (Adiluhung, Kristiyanto, \& Kunta, 2020). Adanya model pengembangan latihan circuit training diharapkan atlet dapat termotivasi, atlet mampu melakukan pukulan yang baik (pukulan backhand) pada saat latihan dan pada saat pertandingan di lapangan.

Penelitian ini bertujuan untuk mengembangkan model latihan circuit training sebagai media pelaksanaan pelayanan pelatihan bulutangkis dengan model latihan circuit training, kemudian menghasilkan buku ajar yang sesuai dan mempermudah atlet belajar ketepatan pukulan backhand. Penelitian ini untuk mempermudah atlet belajar ketepatan pukulan backhand dengan model circuit training, hal ini juga dapat digunakan untuk pelatih dalam melakukan pelatihan bulutangkis untuk menerapkan teknik pukulan bulutangkis (pukulan backhand) di lapangan sehingga diharapkan kualitas backhand peserta didik memiliki pukulan yang baik dan terarah. Selain itu, penelitian ini juga berkontribusi dalam pengembangan ilmu pengetahuan dalam bidang olahraga bulutangkis. 


\section{METODE PENELITIAN}

Model Pengembangan

Suatu model dalam penelitian pengembangan dihadirkan dalam bagian prosedur pengembangan dan penelitian. Berdasarkan model tersebut yang dianut oleh peneliti, maka akan diperoleh sejumlah masukan (input) untuk penyempurnaan produk yang dihasilkan, apakah berupa bahan ajar, media, atau produk-produk yang lain. Ada beberapa model misalnya konseptual, model prosedural, model sistematis dan sebagainya (Punaji, 2015)

Penelitian pengembangan adalah suatu penelitian yang bertujuan untuk mengembangkan suatu produk baru atau menyempurnakan produk yang telah ada (Sugiyono, 2017). Penelitian pengembangan ini termasuk penelitian model pengembangan (Borg \& Gall, 1983). Pengembangan model circuit training diawali dengan: (1) Melakukan analisis kebutuhan dilakukan dengan mengkaji keadaan di lapangan. Pada tahap ini peneliti melakukan observasi dan wawancara dengan pelatih dan atlet PB. Patriot, (2) Pembuatan produk awal pembuatan produk pengembangan model circuit training. Isi dari model circuit training terdiri dari 6 gerakan, (3) Validasi ahli yang terdiri dari validasi desain pembelajaran dan ahli desain bidang keolahragaan khususnya bulutangkis, (4) Mengujicobakan produk model circuit training pada atlet bulutangkis kelompok kecil yang dilaksanakan di lapangan PB. Patriot, (5) Melakukan revisi produk model circuit training berdasarkan hasil masukan dari pelatih dan atlet, (6) Mengujicobakan produk model circuit training pada atlet bulutangkis kelompok sedang yang dilaksanakan di lapangan PB. Patriot, (7) Melakukan revisi produk model circuit training berdasarkan hasil masukan pelatih dan atlet untuk hasil uji coba kelompok sedang, (8) Mengujicobakan produk model circuit training pada atlet bulutangkis kelompok besar yang dilaksanakan di lapangan PB. Patriot, (9) Melakukan revisi produk model circuit training berdasarkan hasil masukan pelatih dan atlet untuk hasil uji coba kelompok besar, (10) Hasil akhir berupa produk yang dihasilkan dari uji lapangan sebagai bentuk pengembangan model latihan circuit training untuk ketepatan pukulan backhand.

Dalam penelitian ini metode pengumpulan data menggunakan angket yang dipilih sendiri oleh responden yang diteliti. Menurut Sugiyono (2017) skala likert digunakan untuk mengukur sikap, pendapat, dan persepsi seseorang atau sekelompok orang tentang fenomena sosial. Oleh karena itu, pengumpulan data dilakukan dengan menggunakan skala likert yang bervariasi dengan pertanyaan-pertanyaan melalui alternatif jawaban dapat dilihat pada tabel 1 .

Tabel 1. Skala Likert

\begin{tabular}{cccc}
\hline No & \multicolumn{1}{c}{ Kriteria } & Skor \\
\hline 1 & Sangat Setuju & ( SS ) & 4 \\
\hline 2 & Setuju & ( S ) & 3 \\
\hline 3 & Tidak Setuju & ( TS ) & 2 \\
\hline 4 & Sangat Tidak Setuju & ( STS ) & 1 \\
\hline
\end{tabular}

Pemberian nilai jawaban atau skor bergerak dari angka 4 sampai angka 1. Kisi-kisi atau Blue Print angket dengan indikator untuk Guru Penjaskes yaitu kemenarikan metode pelatihan, relevansi bahan untuk mengajar dan manfaat bahan ajar yang diajarkan. Sedangkan untuk indikator siswa yaitu kemenarikan bahan sajian ajar yang dipelajari kemudian dalam pembelajaran dan kenyamanan dalam pembelajaran dapat dilihat pada tabel 2 . 
Tabel 2. Blue Print

\begin{tabular}{|c|c|c|c|}
\hline No & Responden & Indikator & Item Pertanyaan \\
\hline \multirow{3}{*}{1} & \multirow{3}{*}{$\begin{array}{l}\text { Pelatih } \\
\text { Bulutangkis }\end{array}$} & Relevansi Materi Pelatihan & $10,11,14,15,16,17$ \\
\hline & & Kemenarikan Metode Pelatihan & $1,2,3,4,5$ \\
\hline & & Manfaat Materi Pelatihan & $6,7,8,9,12,13$ \\
\hline \multirow{3}{*}{2} & \multirow{3}{*}{$\begin{array}{l}\text { Atlet } \\
\text { Bulutangkis }\end{array}$} & Kemudahan dalam Pelatihan & $6,7,8,9,14,15$ \\
\hline & & Kemenarikan Metode Pelatihan & $1,2,3,4,5,11,12,13$ \\
\hline & & Kenyamanan dalam Pelatihan & $10,16,17$ \\
\hline
\end{tabular}

(Sugiyono, 2017)

\section{Uji Coba Produk}

Dalam desain uji coba produk ini ada beberapa hal yang diuraikan, yaitu:

\section{Tempat Penelitian dan Waktu}

Tempat uji coba : Lapangan Bulutangkis PB. Patriot

Alamat : Simowau Sepanjang Kecamatan Taman Kabupaten Sidoarjo

Waktu uji coba : Tanggal 9 Juli 2018 - 19 Oktober 2018

\section{Desain Uji Coba}

Desain uji coba dilakukan untuk mengetahui tingkat kemanfaatan dan kemenarikan produk berupa buku bahan ajar/buku pelatihan model latihan circuit training bulutangkis, maka dilakukan serangkaian validasi kemudian diujicobakan dan direvisi untuk memperoleh hasil produk yang baik berdasarkan perolehan dari tinjauan ahli, hasil uji coba kelompok kecil, dan uji coba kelompok besar. Beberapa rangkaian tahapan yang dilakukan antara lain:

a. Tinjauan ahli materi bulutangkis dan validasi, bertujuan untuk mendapatkan data berupa penilaian, pendapat dan saran terhadap kelayakan isi materi dan sajian materi buku produk pelatihan model latihan circuit training untuk melatih ketepatan pukulan backhand cabang olahraga bulutangkis.

b. Tinjauan ahli desain pembelajaran dan validasi, bertujuan untuk mendapatkan penilaian dan komentar serta saran terhadap desain, tata bahasa dan kelayakan produk pelatihan model latihan circuit training untuk melatih ketepatan pukulan backhand cabang olahraga bulutangkis.

c. Teman sejawat, dalam pelaksanaan uji produk yang dilakukan teman sejawat disini dilakukan oleh 1 pelatih bulutangkis dan atlet di PB. Patriot. Setelah diujicoba oleh teman sejawat beserta atlet dan diberikan angket respon tentang model latihan circuit training untuk ketepatan pukulan backhand cabang olahraga bulutangkis. Penulis akan merevisi bila ada catatan atau kekurangan dari masukan teman sejawat dan atlet bulutangkis.

d. Uji coba kelompok kecil, uji coba kelompok kecil dilakukan setelah melalui uji coba teman sejawat, maka model latihan circuit training untuk ketepatan pukulan backhand cabang olahraga bulutangkis diujicoba kelompok kecil yaitu 2 pelatih beserta 4 atletnya. Setelah melakukan uji coba maka 2 pelatih beserta 4 atletnya diberikan angket respon dan kemudian akan direvisi lagi bila ada catatan dan masukan dari pelatih dan atlet kelompok kecil.

e. Uji coba kelompok besar, setelah uji coba kelompok kecil kemudian model latihan circuit training untuk ketepatan pukulan backhand cabang olahraga bulutangkis diujicoba kelompok yang lebih besar sebanyak 5 pelatih dan beserta 15 atletnya. Setelah melakukan uji coba maka 5 pelatih dan 15 atletnya diberikan angket respon dan kemudian akan direvisi lagi apabila ada catatan dan masukan dari pelatih kelompok besar dan beserta atletnya. 


\section{Teknik Pengumpulan Data}

Teknik analisis data dalam pengembangan model circuit training ini menggunakan angket yang dikembangkan oleh peneliti, kemudian diisi oleh pelatih bulutangkis dan atlet bulutangkis dengan ditandai centang $(\sqrt{ })$ pada option yang telah disediakan. Kemudian dianalisis menggunakan statistik diskriptif yang penyajiannya dalam bentuk hasil data kebutuhan, evaluasi ahli, uji teman sejawat, uji kelompok kecil dan uji kelompok besar. Apabila datanya berupa persentase, proporsi maupun rasio, maka kesimpulan dapat diambil dan disesuaikan dengan permasalahannya. Berikut penggolongan persentase kategori yang digunakan dapat dilihat pada tebel 4 .

Tabel 4. Konversi Tingkat Pencapaian dengan skala 4

\begin{tabular}{cccc}
\hline No & Kategori & Tingkat Pencapaian (\%) & Keterangan \\
\hline 1 & Sangat Baik & $76 \%-100 \%$ & Tidak Perlu Direvisi \\
\hline 2 & Baik & $51 \%-75 \%$ & Tidak Perlu Direvisi \\
\hline 3 & Kurang Baik & $26 \%-50 \%$ & Perlu Direvisi \\
\hline 4 & Tidak Baik & $0 \%-25 \%$ & Direvisi \\
\hline
\end{tabular}

(Arikunto, 2016)

\section{HASIL DAN PEMBAHASAN}

\section{Hasil Pembahasan Proses Pengembangan Model Latihan Circuit Training}

\section{A. Sajian Analisis Data Dari Validasi Ahli Materi Bulutangkis}

Analisis data dari validasi ahli materi bulutangkis menggunakan sepuluh aspek penilaian. Tiap aspek penilaian memiliki empat skala penilaian. Mulai dari kesesuaian dengan sasaran pelatihan dengan nilai empat, kesesuaian dengan kebutuhan belajar siswa/murid renang dengan nilai empat, kesesuaian dengan perkembangan ilpengtek dengan nilai tiga, kebenaran substansi materi yang didukung teori dan fakta serta data terkaita materi ajaran dengan nilai empat, dan manfaat untuk penambahan wawasan pengetahuan dengan nilai empat.

Aspek penilaian selanjutnya berupa kesesuaian dengan penulisan karya ilmah dengan nilai tiga, kejelasan tujuan pembelajaran/pelatihan dengan nilai empat, urutan penyajian meteri ajaran/materi pelatihan dengan nilai tiga, kesesuaian contoh-contoh dan ilustrasi untuk memperjelas materi ajaran/pelatihan dengan nilai tiga, dan kelengkapan informasi pelatihan dengan nilai empat. Jumlah skor yang didapatkan dalam analisis data tersebut sebesar 39. Berdasarkan jumlah skor tersebut, diukur dengan konversi persentase senilai $90 \%$. Kelayakan isi materi bulutangkis dan sajian materi bulutangkis berkategori sangat baik dan isi materi bulutangkis yang disusun tidak perlu direvisi.

\section{B. Sajian dan Analisis Data dari Validasi Ahli Desain Pembelajaran}

Analisis data dari validasi ahli desain pembelajaran memiliki lima aspek penilaian. Pada setiap aspek penilaian memiliki beberapa indikator. Aspek penilaian kesesuaian dengan tujuan pembelajaran memiliki tiga indikator, yaitu kejelasan tujuan pembelajaran, relevansi tujuan pembelajaran dengan kompetensi dasar, dan kesesuaian materi, contoh soal, dan kuis dengan tujuan pembelajaran. Kemudian aspek isi materi memiliki empat indikator, yaitu kejelasan isi materi, contoh soal, dan latihan; kelengkapan isi materi, contoh soal, dan latihan; kebenaran materi; dan kesesuaian permasalahan yang diajukan dengan materi. 
Aspek penilaian tingkat kemampuan siswa memiliki dua indikator, yaitu kesesuaian media dengan karakteristik siswa sasaran dan kesesuaian dengan tingkat kemampuan siswa. Aspek penilaian penyajian media hanya memiliki satu indikator, yaitu sistematika penyajian runtut dari yang mudah ke sulit. Aspek tata bahasa memiliki empat indikator, yaitu kejelasan yang digunakan, kesesuaian kosakata yang digunakan dengan siswa sasaran, ketepatan rumus, notasi, dan istilah yang digunakan, dan kejelasan petunjuk belajar.

Berdasarkan hasil tersebut dikonversikan dalam nilai persentase yaitu 92,30\%. Berdasarkan nilai tersebut dapat didefinisikan kelayakan tata bahasa, sajian materi dan kegrafisan dalam produk berkategori sangat baik. Oleh karena itu desain produk bahan ajar yang disusun tidak pelu direvisi.

\section{Sajian Analisis Data Dari Teman Sejawat}

Indikator angket relevansi materi pelatihan terdiri dari 6 butir yaitu nomor: 10, 11, 14, 15, 16, 17. Keterangan penilaian angketnya yaitu: (10) Bagi saya latihan circuit training merupakan hal baru dan menarik bagi saya, (11) Setiap hari saya selalu menanti jadwal latihan bulutangkis, (14) Tidak ada hal yang sulit kalau hal yang baru dilakukan dengan sungguh-sungguh dan benar, (15) Selama proses pelatihan circuit training itu dilakukan sesuai prosedur maka tidak ada hal yang prinsip mengganggu saya dalam kegiatan pelatihan di lapangan, (16) Saya merasa senang dan nyaman karena bisa mengikuti pelatihan yang baik, (17) Saya tidak merasa terganggu selama proses model pelatihan circuit training diterapkan di lapangan. Analisis data dari indikator kemenarikan metode pelatihan diperoleh $91,67 \%$, berdasarkan perolehan persentase tersebut dapat disimpulkan bahwa hasilnya berada pada kategori sangat baik dan tidak perlu direvisi. Hasil perolehan setiap butir angket dapat dilihat pada tabel 5 .

Tabel 5. Relevansi Materi Pelatihan

\begin{tabular}{lcccccccc}
\hline No Item & 10 & 11 & 14 & 15 & 16 & 17 & Total 22 \\
\hline Relevansi Materi Pelatihan & Nilai & 4 & 3 & 4 & 3 & 4 & 4 & Total 24 \\
\hline
\end{tabular}

Indikator angket kemenarikan metode pelatihan terdiri dari 5 butir yaitu nomor: 1, 2, 3, 4, 5. Keterangan penilaian angketnya yaitu: (1) Metode pelatihan yang disajikan dapat memberikan motivasi atlet bulutangkis, (2) Saya termotivasi untuk mengikuti kembali latihan lagi, (3) Saya selalu menunggu model latihan yang harus saya kuasai selanjutnya, (4) Saya selalu antusias dalam mengikuti pelatihan bulutangkis, (5) Saya merasa senang dan nyaman karena bisa mengikuti pelatihan yang baik. Analisis data dari indikator relevansi bahan untuk melatih diperoleh 90\%, maka hasil dalam kategori sangat baik dan tidak perlu ada revisi. Hasil perolehan setiap butir angket dapat dilihat pada tabel 6.

Tabel 6. Kemenarikan Metode Pelatihan

\begin{tabular}{lccccccc}
\hline No Item & & $\mathbf{1}$ & $\mathbf{2}$ & $\mathbf{3}$ & $\mathbf{4}$ & $\mathbf{5}$ & Total 18 \\
\hline Kemenarikan Metode Pelatihan & Nilai & 4 & $\mathbf{3}$ & $\mathbf{4}$ & $\mathbf{3}$ & $\mathbf{4}$ & Total 20 \\
\hline
\end{tabular}

Indikator angket manfaat materi pelatihan terdiri dari 6 butir yaitu nomor: $6,7,8,9$, 12, 13. Keterangan penilaian angketnya yaitu: (6) Saya merasa lebih mudah dalam melakukan berbagai macam gerakan yang sudah diinstruksikan oleh pelatih, (7) Menurut saya metode latihan circuit training yang saya jalani tidak terlalu sulit untuk 
dilakukan di lapangan, (8) Setelah menguasai latihan circuit training, saya lebih mudah dalam melakukan pukulan backhand, (9) Melalui metode latihan circuit training yang diterapkan pelatih, saya lebih cepat menguasai teknik pukulan backhand, (12) Belajar olahraga bulutangkis membuat pengalaman saya menjadi bertambah, (13) Mengikuti latihan bulutangkis saya merasa lebih percaya diri dan badan saya merasa lebih sehat. Analisis data dari indikator manfaat materi pelatihan diperoleh $87,5 \%$, maka hasil dalam kategori sangat baik dan tidak perlu ada revisi. Hasil perolehan setiap butir angket dapat dilihat pada tabel 7 .

Tabel 7. Manfaat Materi Pelatihan

\begin{tabular}{lcccccccc}
\hline No Item & & 6 & 7 & 8 & 9 & 12 & 13 & Total 21 \\
\hline Manfaat Materi Pelatihan & Nilai & 4 & 3 & 4 & 4 & 3 & 3 & Total 24 \\
\hline
\end{tabular}

Dari perhitungan dan konversi persentase dari manfaat bahan ajar yang dilatihkan diperoleh $87,5 \%$. Berdasarkan persentase yang diperoleh, produk tersebut termasuk kategori sangat baik dan tidak perlu direvisi. Jadi analisis dari ketiga indikator mulai dari indikator relevansi materi pelatihan diperoleh 91,67\%, indikator kemenarikan metode pelatihan diperoleh $90 \%$ dan indikator manfaat materi pelatihan diperoleh $87,5 \%$, maka dari ketiga indikator tesebut bila dijumlahkan menjadi $89,7 \%$. Jadi produk sangat baik dan layak dilanjutkan ke tahap berikutnya.

\section{Sajian Analisis Data Dari Atlet Bulutangkis Teman Sejawat}

Indikator angket kemudahan dalam pelatihan terdiri dari 6 butir yaitu nomor: 6, 7, 8, 9, 14, 15. Keterangan penilaian angketnya yaitu: (6) Saya merasa lebih mudah dalam melakukan berbagai macam gerakan yang sudah diinstruksikan oleh pelatih, (7) Menurut saya metode latihan circuit training yang saya jalani tidak terlalu sulit untuk dilakukan di lapangan, (8) Setelah menguasai latihan circuit training, saya lebih mudah dalam melakukan pukulan backhand, (9) Dengan metode latihan circuit training yang diterapkan pelatih, saya lebih cepat menguasai teknik pukulan backhand, (14) Tidak ada hal yang sulit kalau hal yang baru dilakukan dengan sungguh-sungguh dan benar, (15) Selama proses pelatihan circuit training itu dilakukan sesuai prosedur maka tidak ada hal yang prinsip mengganggu saya dalam kegiatan pelatihan di lapangan. Analisis data dari indikator kemudahan dalam pelatihan diperoleh 87,5\%, maka berdasarkan perolehan persentase berikut dapat disimpulkan bahwa hasil tersebut berada pada kategori sangat baik dan tidak perlu direvisi. Hasil perolehan setiap butir angket dapat dilihat pada tabel 8 .

Tabel 8. Kemudahan Dalam Pelatihan

\begin{tabular}{lcccccccc}
\hline No Item & & 6 & 7 & 8 & 9 & 14 & 15 & Total 22 \\
\hline Kemudahan dalam Pelatihan & Nilai & 4 & 3 & 4 & 3 & 4 & 4 & Total 24 \\
\hline
\end{tabular}

Indikator angket kemenarikan metode pelatihan terdiri dari 8 butir yaitu nomor: 1, 2, $3,4,5,11,12,13$. Keterangan penilaian angketnya yaitu: (1) Metode pelatihan yang disajikan dapat memberikan motivasi atlet bulutangkis, (2) Saya termotivasi untuk mengikuti kembali latihan lagi, (3) Saya selalu menunggu model latihan yang harus saya kuasai selanjutnya, (4) Saya selalu antusias dalam mengikuti pelatihan bulutangkis, (5) Saya merasa senang dan nyaman karena bisa mengikuti pelatihan yang baik, (11) Setiap hari saya selalu menanti jadwal latihan bulutangkis, (12) Belajar olahraga 
bulutangkis membuat pengalaman saya menjadi bertambah, (13) Dengan mengikuti latihan bulutangkis, saya merasa lebih percaya diri dan badan saya merasa lebih sehat. Analisis data dari indikator kemenarikan metode pelatihan diperoleh 81,25\%, maka berdasarkan perolehan persentase berikut dapat disimpulkan bahwa hasil tersebut berada pada kategori hasil sangat baik dan tidak perlu ada revisi. Hasil perolehan setiap butir angket dapat dilihat pada tabel 9 .

Tabel 9. Kemenarikan Metode Pelatihan

\begin{tabular}{lcccccccccc}
\hline No Item & & $\mathbf{1}$ & $\mathbf{2}$ & $\mathbf{3}$ & $\mathbf{4}$ & $\mathbf{5}$ & $\mathbf{1 1}$ & $\mathbf{1 2}$ & $\mathbf{1 3}$ & Total 26 \\
\hline Kemenarikan Metode Pelatihan & Nilai & $\mathbf{3}$ & $\mathbf{4}$ & $\mathbf{3}$ & $\mathbf{3}$ & $\mathbf{3}$ & $\mathbf{3}$ & $\mathbf{4}$ & $\mathbf{3}$ & Total 32 \\
\hline
\end{tabular}

Indikator angket kenyamanan dalam pelatihan terdiri dari 3 butir yaitu nomor: 6,7 , 8. Keterangan penilaian angketnya yaitu: (6) Saya merasa lebih mudah dalam melakukan berbagai macam gerakan yang sudah diinstruksikan oleh pelatih, (7) Menurut saya metode latihan circuit training yang saya jalani tidak terlalu sulit untuk dilakukan di lapangan, (8) Setelah menguasai latihan circuit training, saya lebih mudah dalam melakukan pukulan backhand. Dari perhitungan dan konversi persentase dari manfaat bahan ajar yang dilatihkan diperoleh 83,33\%, maka hasil dalam kategori sangat baik dan tidak perlu direvisi. Hasil perolehan setiap butir angket dapat dilihat pada tabel 10 .

Tabel 10. Kenyamanan dalam Pelatihan

\begin{tabular}{llllll}
\hline No Item & & $\mathbf{6}$ & $\mathbf{7}$ & $\mathbf{8}$ & Total 10 \\
\hline Kenyamanan dalam Pelatihan & Nilai & 3 & 4 & 3 & Total 12 \\
\hline
\end{tabular}

Berdasarkan analisis dari ketiga indikator mulai dari indikator kemudahan materi pelatihan diperoleh $87,5 \%$, indikator kemenarikan metode pelatihan diperoleh $81,25 \%$ dan indikator kenyamanan dalam pelatihan diperoleh $83,33 \%$. Maka dapat disimpulkan bahwa hasil tersebut berada pada kategori sangat baik dari ketiga indikator tesebut bila dijumlahkan menjadi $83,82 \%$ dan layak dilanjutkan ke tahap berikutnya.

\section{E. Sajian dan Analisis Data dari Pelatih Bulutangkis Kelompok Kecil}

Analisis data dari ketiga indikator mulai dari indikator relevansi materi pelatihan yang diperoleh $89,58 \%$, indikator kemenarikan metode pelatihan yang diperoleh $92,5 \%$ dan indikator manfaat materi pelatihan yang diperoleh 91,67\%, maka dari ketiga indikator tersebut bila dijumlahkan menjadi 91,18\%. Oleh karena itu produk sangat baik dan layak dilanjutkan ke tahap berikutnya.

\section{F. Sajian dan Analisis Data dari Atlet Bulutangkis Kelompok Kecil}

Analisis data dari ketiga indikator mulai dari indikator kemenarikan bahan sajian yang dipelajari diperoleh $90.62 \%$, indikator kemudahan dalam pembelajaran diperoleh $83.33 \%$, dan indikator kenyamanan dalam pembelajaran diperoleh $84.37 \%$, maka dari ketiga indikator tersebut bila dijumlahkan menjadi $86,8 \%$. Oleh karena itu berdasarkan perolehan persentase tersebut dapat disimpulkan bahwa produk berada pada kategori sangat baik dan layak dilanjutkan ke tahap berikutnya. 


\section{G. Sajian dan Analisis Data dari Pelatih Bulutangkis Kelompok Besar}

Analisis data dari ketiga indikator mulai dari indikator relevansi materi pelatihan diperoleh $93,33 \%$, indikator kemenarikan dalam pelatihan diperoleh $97 \%$ dan indikator manfaat materi pelatihan diperoleh $90,83 \%$, maka dari ketiga indikator tersebut bila dijumlahkan menjadi $93,52 \%$. Oleh karena itu produk sangat baik dan layak dilanjutkan ke tahap berikutnya.

\section{H. Sajian dan Analisis Data dari Atlet Bulutangkis Kelompok Besar}

Analisis data dari ketiga indikator mulai dari indikator kemudahan dalam pelatihan diperoleh 91,67\%, indikator kemenarikan metode pelatihan diperoleh 97,71\% dan indikator kenyamanan dalam pelatihan diperoleh $91,67 \%$, maka dari ke tiga indikator tersebut bila dijumlahkan menjadi $94,51 \%$. Oleh karena itu produk sangat baik dan produk dinyatakan selesai dan layak digunakan. Dengan kata lain produk sudah selesai dalam tahap uji coba.

Penelitian ini secara umum dapat dikatakan efektif dalam meningkatkan ketepatan pukulan backhand pada olahraga bulutangkis. Hal ini memiliki hasil yang sama dengan penelitian sebelumnya, seperti pada penelitian Babalola (2011) yang menunjukkan pelatihan sirkuit (circuit training) yang berpengaruh pada kecepatan, kelincahan, fleksibilitas, kekuatan otot tungkai dan daya tahan otot jantung setelah minggu ke delapan. Selain itu, pada penelitian Slamet, Sulastio, dan Wiranata (2018) yang menunjukkan ada efek dari pelatihan sirkuit pelatihan daya tahan dalam olahraga bulutangkis yang diujicoba pada atlet klub RTV. Penelitian Gokulkrishnan (2018) juga menunjukkan berkat pelatihan sirkuit dan pelatihan interval meningkat signifikan pada kapasitas Vital dan VO2 max pada pebulutangkis wanita. Hal ini juga senada dengan penelitian Arnando (2018) yang menunjukkan bahwa ada pengaruh yang signifikan dari metode pelatihan sirkuit untuk meningkatkan kapasitas VO2 Max atlet bulutangkis UNP. Penelitian ini menghasilkan bagaimana peningkatan kualitas backhand atlet dengan latihan circuit training. Begitu pula penelitian lain juga menguji kualitas backhand atlet dengan metode yang lain, seperti pada penelitian Rahmat, Asmawi, Tangkudung, Dlis, dan Saputra (2019) yang menunjukkan peningkatan kualitas backhand yang ditingkatkan dengan pelatihan berbasis variasi dan hal ini juga mampu menciptakan suasana yang menyenangkan dan mencegah waktu yang membosankan.

\section{KESIMPULAN}

Pengembangan model latihan circuit training untuk menunjang ketepatan pukulan backhand cabang olahraga bulutangkis memberikan dampak yang signifikan. Dari penelitian ini dapat diambil suatu simpulan bahwa: (1) Model latihan circuit training bulutangkis pelatih dan atlet di PB. Patriot menjadi lebih efektif, (2) Model circuit training yang efektif dapat membantu suasana latihan di PB. Patriot.

Validitas penelitian pengembangan ini berdasarkan hasil validasi oleh ahli materi dan ahli desain pembelajaran. Hasil validasi dari kedua ahli tersebut menunjukkan dalam kategori sangat baik. Hasil penelitian berupa model latihan circuit training untuk menunjang ketepatan pukulan backhand layak diimplementasikan sebagai media pembelajaran pelatihan bulutangkis.

Peneliti berharap adanya sosialisasi penggunaan media pembelajaran ini dalam skala yang lebih luas lagi. Penggunaan media pembelajaran ini di sekolah-sekolah sangat diperlukan untuk menunjang keterampilan dasar pukulan dalam olahraga bulutangkis, sehingga penelitian ini dapat bermanfaat bagi lingkup yang lebih besar. 


\section{DAFTAR PUSTAKA}

Abdullah, S. A. (2014). Effect of high intensity interval circuit training on the development of specific endurance to some of essential skills in youth badminton players. Journal of Advanced Social Research, 4(3), 77-85.

Adiluhung, R., Kristiyanto, A., \& Kunta, S. (2020). The Development of Backhand Drive Stroke Technique Training in Audiovisual Based for Beginner Badminton Athletes. Quality in Sport, 2(6), 14-27. http://dx.doi.org/10.12775/QS.2020.008.

Arikunto, S. (2016). Dasar-dasar Evaluasi Pendidikan. Jakarta: Jakarta: Bumi Aksara.

Arnando, M. (2018). The effect of circuit training method towards the improvement of vo2 max for badminton athletes. In 3rd International Conference on Sports Science, Health and Recreation (pp. 124-130). Universitas Negeri Padang.

Babalola, J. F. (2011). Effects of 8-weeks circuit training programme on physiological and performance characteristics of university racket game players. Journal of Asian Scientific Research, 1(1), 143-149.

Babu, M. S., \& Kumar, P. P. S. P. (2013). The effect of selected circuit training exercises on sprinters of high school girls. International Journal of Science and Research (IJSR), 2(11), 401-407.

Bompa. (2015). Periodization Training for Sports. Unitted States: Human Kinetics.

Borg, W. R., \& Gall, M. D. (1983). Educational Research: An Introduction. New York: Longman.

Gokulkrishnan, G. (2018). Effect of circuit training and interval training on vital capacity and VO2 max in women badminton players. International Journal of Physiology, Nutrition and Physical Education, 3(2), 1204-1206.

Juang, B. R., \& Widodo, A. (2015). Analisis Kelebihan dan Kelemahan Keterampilan Teknik Bermain Bulutangkis pada Pemain Tunggal Putra Terbaik Indonesia Tahun 2014. Jurnal Kesehatan Olahraga, 3(1), 109-117.

Kusuma, L. S. W. (2017). Pengaruh latihan circuit training terhadap peningkatan vo2max pemain sepak bola Ekacita FC. Gelora: Jurnal Pendidikan Olahraga dan Kesehatan, 4(2), 80-83.

Maksum, A. (2011). Psikologi Olahraga Teori dan Aplikasi. Surabaya: Unesa University Press.

Mohanta, N., Kalra, S., \& Pawaria, S. (2019). A Comparative Study of Circuit training and Plyometric Training on Strength, Speed and Agility in State Level Lawn Tennis Players. Journal of Clinical and Diagnostic Research, 13(12), 5-10. https://doi.org/10.7860/JCDR/2019/42431.13348 
Mutohir, T. C., Muhyi, M., \& Fenanlampir, A. (2011). Berkarakter dengan Berolahraga, Berolahraga dengan Berkarakter. Surabaya: PT. Java Pustaka Group.

Poole, J. (2005). Belajar Bulutangkis. Bandung: CV Pionir Jaya.

Prasetyo, Y. (2013). Kesadaran Masyarakat Berolahraga untuk Peningkatan Kesehatan dan Pembangunan Nasional. Medikora, 11(1), 219-228. https://doi.org/10.21831/medikora.v11i2.2819

Pratomo, A. U. D., Sugiharto., \& Subiyono, H. S. (2013). Perbedaan Hasil Latihan Umpan Balik Lob Langsung dan Lob Tak Langsung Terhadap Ketepatan Lob Dalam Olahraga Bulutangkis Di Pb Tugu Muda Kota Semarang. Journal of Sport Sciences and Fitness, 2(1), 1-5.

Punaji. (2015). Metode Penelitian Pendidikan \& Pengembangan. Malang: PT Kharisma Putra Utama.

Putra, G. I., \& Sugiyanto, F. (2016). Pengembangan pembelajaran teknik dasar bulu tangkis berbasis multimedia pada atlet usia 11 dan 12 tahun. Jurnal Keolahragaan, 4(2), 175. https://doi.org/10.21831/jk.v4i2.10893

Rahman, F. J. (2018). Peningkatan Daya Tahan, Kelincahan, dan Kecepatan pada Pemain Futsal: Studi Eksperimen Metode Circuit Training. Jurnal SPORTIF: Jurnal Penelitian Pembelajaran, 4(2), 264-279. https://doi.org/10.29407/js_unpgri.v4i2.12466.

Rahmat, A. R., Asmawi, M. A., Tangkudung, J., Dlis, F. D., \& Saputra, S. A. (2019). Development of exercise smash, lob and backhand models in bulutangkis based on training variation for beginner. Journal of Education, Health and Sport, 9(7), 681690. http://dx.doi.org/10.5281/zenodo.3354614.

Romadhoni, D. L., Herawati, I., \& Pristianto, A. (2018). Pengaruh pemberian circuit training terhadap peningkatan vo2max pada pemain futsal di Maleo Futsal Magetan. Jurnal Kesehatan, 11(1), 43-48. https://doi.org/10.23917/jurnal\%20kesehatan.v11i1.7004.

Slamet, S., Sulastio, A., \& Wiranata, A. (2018). The effect of training circuit exercise on the resistance of badminton game for the atlet club of RTV Pekanbaru. In Proceedings of the UR International Conference on Educational Sciences (115122). Pekanbaru, Universitas Riau.

Sonchan, W., Moungmee, P., \& Sootmongkol, A. (2017). The effects of a circuit training program on muscle strength, agility, anaerobic performance and cardiovascular endurance. International Journal of Medical, Health, Biomedical, Bioengineering and Pharmaceutical Engineering, 11(4), 170-173.

Song, X., Peng, Y., Hu, B., \& Liu, W. (2020). Characterization of the fine hand movement in badminton by a smart glove. Instrumentation Science \& Technology, 48(4), 443-458. https://doi.org/10.1080/10739149.2020.1737814 
Sugiyono. (2017). Metode Penelitian dan Pengembangan. Bandung: Alfabeta.

Taufan, A., Dewantara, B., \& Alsaudi. (2016). Pengaruh Strategi Pembelajaran dan Konsep Diri terhadap Keterampilan Smash Bulutangkis. Journal Sport Area, 1(2), 10-22. https://doi.org/10.25299/sportarea.2016.vol1(2).383.

Trisandy, M., \& Sugiyanto. (2017). Peningkatan vo2 max melalui latihan circuit training pada siswa kelas VIII.4 SMP Negeri 4 Kota Bengkulu. Kinestetik: Jurnal Ilmiah Pendidikan Jasmani, 1(2), 70-85. https://doi.org/10.33369/jk.v1i2.3468.

Yani, A. (2015). Pengaruh Metode Latihan Sirkuit, Metode Konvensional dan Motivasi Berprestasi terhadap Kemampuan Lompat Jauh Gaya Jongkok. Primary: Jurnal Pendidikan Guru Sekolah Dasar, 4(2), 134-142. http://dx.doi.org/10.33578/jpfkip.v4i2.2947. 